\title{
The Impact of External Environment on Competitive Advantage through SME Differentiation Strategy in Central Java
}

\author{
Yadi Fakhruzein Terang Jaya*, Muhammad Nasir, Pramesti Dewi \\ Management Science, Sultan Agung Islamic University, Kaligawe Raya Street No.KM, Terboyo Kulon, Genuk District, Semarang City,
} Central Java 50112, Indonesia

Received December 1, 2020; Revised February 6, 2021; Accepted February 24, 2021

Cite This Paper in the following Citation Styles

(a): [1] Yadi Fakhruzein Terang Jaya, Muhammad Nasir, Pramesti Dewi, "The Impact of External Environment on Competitive Advantage through SME Differentiation Strategy in Central Java," Universal Journal of Management, Vol. 9 , No. 2, pp. 38 - 43, 2021. DOI: 10.13189/ujm.2021.090202.

(b): Yadi Fakhruzein Terang Jaya, Muhammad Nasir, Pramesti Dewi (2021). The Impact of External Environment on Competitive Advantage through SME Differentiation Strategy in Central Java. Universal Journal of Management, 9(2), 38 - 43. DOI: 10.13189/ujm.2021.090202.

Copyright $\mathrm{C} 2021$ by authors, all rights reserved. Authors agree that this article remains permanently open access under the terms of the Creative Commons Attribution License 4.0 International License

\begin{abstract}
The competitiveness of Small and Medium Enterprises (SMEs) in Indonesia is still very low and vulnerable compared to increasingly uncertain business environment dynamics. Changing conditions require SMEs carry out continuous and systematic analysis of the external environment, so that owners who carry out strategic planning get information through various sources in the external environment. This is done to maintain a competitive advantage and as an effort to realize unexpected opportunities and progress. This study aims to: (1) measure the impact of external environment on differentiation strategy in SMEs in Central Java; (2) measure the impact of external environment on competitive advantage in SMEs in Central Java; (3) measure the impact of differentiation strategy on competitive advantage in SMEs in Central Java. The type of research used in this study is causal research. The method used in this research is quantitative. The population that will be used and examined in this study is all SMEs in Central Java, while the samples in this study were 180 SMEs in Central Java with a multivariate type sample size. Data collection technique was conducted using a questionnaire. This study uses Partial Least Square (PLS) for its analysis technique. The results in this study indicate that: (1) External Environmental has a significant effect on Differentiation Strategy; (2) External Environmental has a significant impact on Competitive Advantage. And (3)
\end{abstract}

Differentiation Strategy has a significant effect on Competitive Advantage.

Keywords External Environment, Differentiation Strategy, Competitive Advantage, Research, Impact

\section{Introduction}

The development of globalization has an enormous impact on various sectors of the country, including Indonesia. Many companies in Indonesia compete for opportunities for business with high investment value. The development of a business environment that is full of uncertainty, increasingly complex, and very dynamic requires entrepreneurs to change and be adaptive. McArthur and Nystry (Gorondutse \& Hilman, 2017) revealed that environmental society is related to strategy and consequently affects business performance, and this means that ecological community changes the relationship between design and performance Goll and Rasheed in (Gorondutse \& Hilman, 2017). As such, efforts to develop and empower SMEs have become increasingly critical due to the dramatic changes in the business environment faced.

Meanwhile, SMEs demanded to be able to compete so 
that the existence of the business continues. However, SMEs in Indonesia are still low in competitiveness and prone to a dynamic business environment. This condition has an impact on the low productivity produced, and the existence of the business is threatened. This condition is due to the low adaptation and responsiveness of SMEs in facing the challenges of the external business environment, due to the limited internal capabilities they have (Zimmerer, 2005).

SMEs have a significant part in the Indonesian economy. Micro, Small, and Medium Enterprises (MSME) are economic activities of the people who stand alone and small-scale managed by community groups or families. MSMEs much urge the national economy because it can absorb very high unemployment and contribute high Gross Domestic Product (GDP). In 2018, there were 64.2 million units of MSMEs that we're able to absorb $97 \%$ of the total workforce and $99 \%$ of the full employment (Katadata, 2020). MSMEs contribute $96 \%$ of the 170 million crews or around 121 million, with an annual growth of 5\% (Hartomo, 2019). In 2018 the MSME sector contributed IDR 8,400 trillion to the Gross Domestic Product (GDP). This figure is equivalent to $60 \%$ of Indonesia's IDR14,000 trillion GDP in 2018 (Hartomo, 2019). In other words, MSMEs are referred to as the backbone of the State's economy. MSMEs in Indonesia are challenging to develop in the market due to internal problems such as low quality of human resources such as lack of skilled human resources, lack of entrepreneurial orientation, low technology and management, and low market orientation. SMEs have several internal problems, two of which are entrepreneurship and market orientation. These two things are important in achieving success, especially for MSMEs (Daengs GS \& Soemantri, 2020).

The rapid change created by the phenomenon of globalization puts pressure on organizations to adapt to changing environments in which organizations are complex and in quick transition. At the same time, competition is fierce. Chenhall and Morris (Darya, 2012) emphasize that in uncertain conditions, extensive, timely information is needed. This condition is very logical because decentralized managers, who are forced to adapt to environmental uncertainties, need useful information to guide and solve problems (Darya, 2012). In a rapidly changing world, businesses are required to adapt to the latest changes and knowledge they have to maintain their competitive strength (Liao et al., 2010). In addition to being a unique resource for individuals and organizations, Information also facilitates adaptation, to learn business strategies, to solve problems, and to create core competencies (Liao et al., 2010). To respond and adapt to the changing needs of the market, SMEs must conduct an analysis of the external environment(Morden, 1993).

The environment includes all factors that exist outside the company but is closely related to the company (Türkay et al., 2011). Changes in current conditions require SMEs to study the external environment continuously and systematically. For this purpose, company leaders must carry out strategic planning in obtaining information in the external environment. This is done to maintain the company's competitive advantage, which in turn will result in unplanned opportunities, threats, and advances. They evaluate, control, and disseminate this information throughout the company (Türkay et al., 2011). As mentioned earlier, in many cases, businesses make changes and develop new processes using strategic analysis to deal with a dynamic business environment (Türkay et al., 2011).

Companies must analyze the competitive environment, choose a good strategy, and find the resources needed to implement the company's plan to achieve a sustainable competitive advantage are not easy. According to Barney (Job et al., 2016), companies that have a competitive advantage are companies that use value creation strategies that are not carried out by competitors. Implementation of a good strategy in the company requires a different strategy from competitors so that it will encourage a competitive advantage compared to competitors. This strategy is called a differentiation strategy. The emergence of pressure for companies to achieve sustainable competitive advantage is due to several factors, including domestic and international market competition, customer demands, and rapid technological advances. For example, in the Australian manufacturing sector, it is increasingly evident that companies struggle to compete based on low costs, supporting a differentiation strategy (Adema \& Roehl, 2010). Thus, when labor costs become very high in developed countries (such as Australia) compared to developing countries, Australian manufacturing companies tend to look for competitive advantages by producing products with more valuable features. The features such as product quality, product flexibility, or reliable delivery. However, sustainable competitive advantage is not just about strategic choices. To support the company's strategic priorities, both management and accounting literature must understand the importance of a good organizational structure and system. Indeed, successful organizations are those who implement organizational structures and systems that facilitate the achievement of their strategic choices (Adema \& Roehl, 2010). The performance measurement system (PMS) is increasingly recognized as a vital component of an organizational structure, which, when aligned with the company's strategic priorities, leads to superior organizational performance (Adema \& Roehl, 2010).

Suryana (Nurlina et al., 2013) states that MSMEs are proven to have the ability to face the national economy and can survive the economic crisis in Indonesia because small businesses are quite flexible and adapt quickly. Ebb and flow and direction of market demand. Meanwhile, SMEs' spirit of entrepreneurship is as a trigger and a driver in generating business success and contributing to 
the progress of the national economy.

Thus, efforts to develop and empower SMEs become increasingly critical to the dramatic changes in the business environment they face. Meanwhile, SMEs demanded to be able to compete so that the existence of the business continues. However, SMEs in Indonesia are still low in competitiveness and prone to a dynamic business environment. This condition has an impact on the low productivity generated, and the existence of the business threatened. This condition is due to the low adaptability and responsiveness of SMEs in facing the challenges of the external business environment due to the limited internal capabilities they have. The focuses of this study are SMEs in Central Java.

\section{Objectives}

Based on the phenomena and problems raised, the purpose of this study is:

a) to analyze the effect of External Environment on differentiation strategy in SMEs in Central Java,

b) to analyze the effect of External Environment on competitive advantage in SMEs in Central Java,

c) to analyze the effect of differentiation strategy on competitive advantage in SMEs in Central Java.

\section{Methods}

\subsection{Research Type}

The type of research used in this study is causal research. Causal analysis is a type of conclusive research aiming at obtaining evidence related to causal relationships (Malhotra \& Dash, 2009). The method used in this research is quantitative, is research that uses data of numbers so that it can be processed and analyzed statistically (Sekaran 2013).

\subsection{Population and Sample}

The population is the whole group of people, events, or things that investigators want to investigate (Sekaran, 2013). The populations that will be used and examined in this study are all SMEs in Central Java.

According to (Sekaran 2013), the sample is part of the population. It consists of several members chosen from the population. The sample size used is a multivariate type. This multivariate type sample size means that the sample size must be several times larger than the number of variables to be analyzed. This sample size refers to the guidelines for measuring samples according to Hair et al. in (Ferdinand 2014), which uses 5-10 times the indicator variable. So this study uses a sample of $10 \times 18=180$ respondents so that the sample used in this study was SMEs in Central Java as many as 180 respondents.

\subsection{Data Collection Technique}

This study used survey method as data collection technique. According to (Sugiyono 2016), the survey research method is research that uses a questionnaire as a research tool for both small and large samples.

\subsection{Data Analysis Technique}

Use SEM PLS because the research model is multi-lane and reflective (Ghozali, 2012).

\section{Result}

\subsection{Inner Model}

Table 1. R-Square Values

\begin{tabular}{|c|c|}
\hline & $R$-Square \\
\hline External Environment $(\mathrm{X})$ & \\
\hline Differentiation Strategy $(\mathrm{Z})$ & 0.090 \\
\hline Competitive Advantage $(\mathrm{Y})$ & 0.340 \\
\hline
\end{tabular}

The results of the R-square test show that the External Environment variable has an R2 of 0.090, which means the "weak" model. In contrast, the External Environment and Differentiation Strategy that affects Competitive Advantage has an R2 of 0.340 , which means the "Moderat" model.

Based on the analysis using partial least square analysis, the following model results were obtained.

Based on the Inner PLS diagram in the figure above, it can be concluded that exogenous variables are External Environment. Furthermore, Endogenous variables in the inner model under study are Competitive Advantage and intervening variables, namely the Differentiation Strategy variable. The results in Figure 1 show the following obtained structural equation:

$$
\begin{gathered}
Z=0.301 X \\
Y=0.329 X+0.392 Z
\end{gathered}
$$




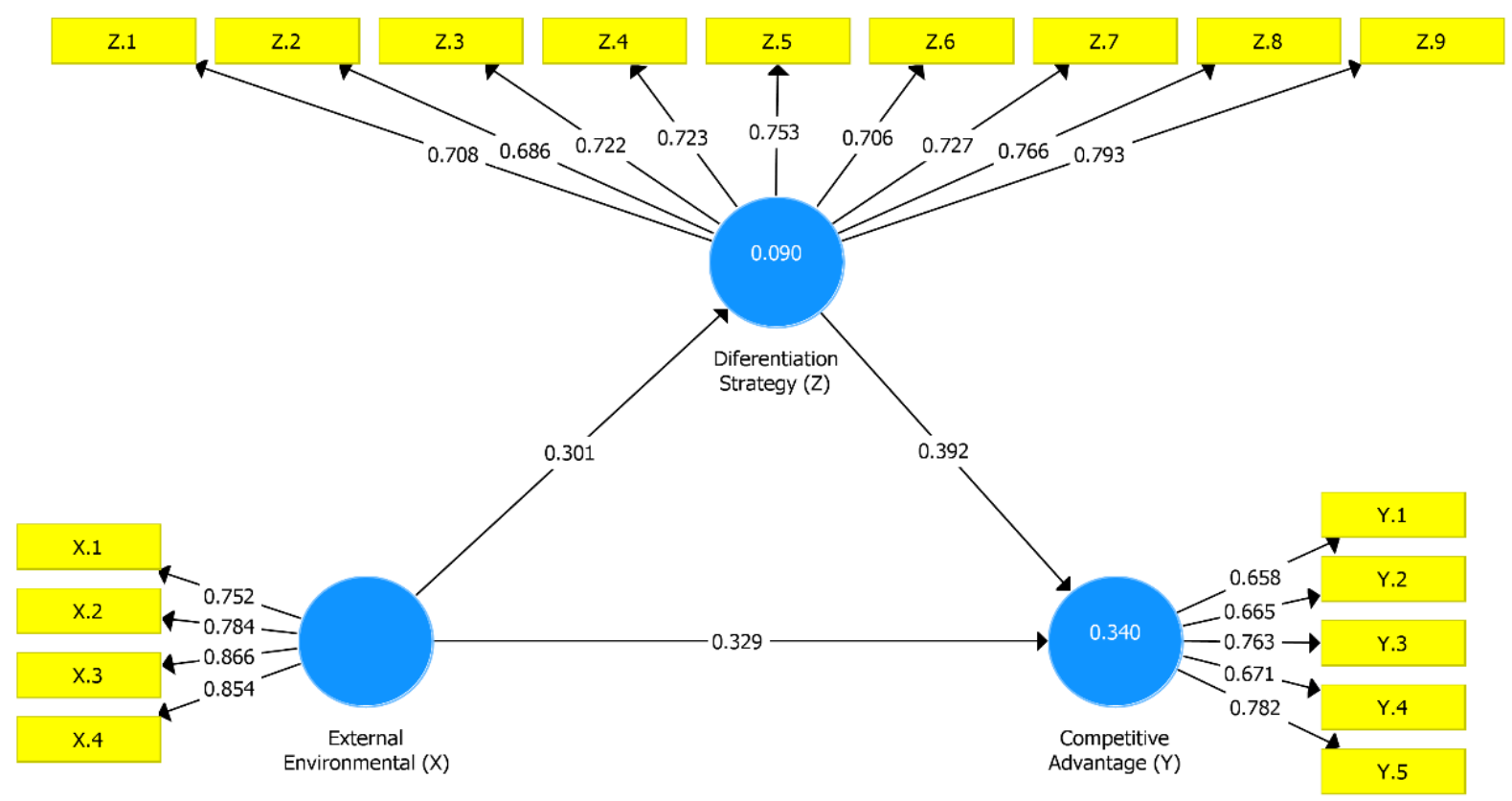

Figure 1. Inner PLS Model

Table 2. Hypothesis Testing Results

\begin{tabular}{lcccc}
\hline & $\begin{array}{c}\text { Original } \\
\text { Sample }\end{array}$ & $\begin{array}{c}\text { Sample } \\
\text { Mean }\end{array}$ & $\begin{array}{c}\text { Standard } \\
\text { Deviation }\end{array}$ & $\begin{array}{c}\text { T } \\
\text { Statistics }\end{array}$ \\
\hline External Environment $(\mathbf{X})$-> Differentiation Strategy (Z) & 0301 & 0.317 & 0.072 & 4,184 \\
External Environment $(\mathbf{X})$-> Competitive Advantage (Y) & 0.329 & 0.330 & 0.071 & 4,616 \\
Differentiation Strategy $(\mathbf{Z})$ - > Competitive Advantage (Y) & 0.392 & 0.399 & 0.068 & 5,783 \\
\hline
\end{tabular}

\subsection{Hypothesis Testing Results}

Based on the results of testing the hypothesis above, the results obtained are:

1. External Environment has a significant effect on the Differentiation Strategy, and this is evidenced by the T-statistic value of 4,184 or $>1.96$.

2. External Environment has a significant effect on Competitive Advantage and this evidence from the T-statistic value of 4,616 or $>1.96$.

3. Differentiation Strategy has a significant effect on Competitive Advantage and this evidence from the T-statistic value of 5,783 or $>1.96$.

\section{Discussion}

\subsection{Effect of External Environment Against Differentiation Strategy}

External Environment has a significant influence on the Differentiation Strategy in SMEs in Central Java because the T-statistic value is 4,184 or $>1.96$. This finding shows that the External Environment has a great effect on differentiation strategy with a positive influence direction. It shows that number of differentiation strategies in business operations is also influenced by the quality of the external environment owned by SMEs in Central Java. The findings in this study support (Ingga, 2009) research which found that there was a relationship between the external environment and the differentiation strategy. But the results do not support with the Nurlina's et al findings which prove that the external environment does not directly influence the differentiation strategy (Nurlina et al., 2013).

\subsection{The Influence of External Environment Against Competitive Advantage}

External Environment has a significant influence on Competitive Advantage in SMEs in Central Java because the T-statistic value is 4,616 or $>1.96$. This finding shows that the External Environment has a significant effect on Competitive Advantage with the direction of positive influence. This finding indicates that the better the external environment in the business operations owned by SMEs in Central Java will further enhance the competitive advantage of SMEs in conducting their business. The findings in this study support the results of the study of Kraja and Osmani (Kraja \& Osmani, 2015), who found that external factors had a positive influence on SMEs' competitive advantage. Nurlina et al., (2013) on their paper also found similar results, which found that the value of a competitive advantage could directly be due to 
the external environment.

\subsection{The Effect of Differentiation Strategy on Competitive Advantage}

Differentiation Strategy has a significant influence on Competitive Advantage in SMEs in Central Java because the T-statistic value is 5,783 or $>1.96$. This finding shows that the Differentiation Strategy has a significant positive effect on Competitive Advantage so that can interpret by that the higher the level of strategy differentiation implemented by SMEs in Central Java will increasingly have an impact on increasing the excellence of SMEs in competing. This finding supports (Putra et al., 2018) result who found that differentiation strategies can create a competitive advantage. The same resolve is also proven by (Job et al., 2016), which shows in his research that management decision-making on competitive advantage affected by product differentiation. Likewise, (Paryanti 2015) proves that the differentiation strategy can influence competitive advantage.

\section{Conclusions}

External Environment has a significant influence on the Differentiation Strategy of SMEs in Central Java. The external environment has a role in the implementation of a differentiation strategy. It is believed by researchers the influence of changes in rapid changes in the situation makes SMEs have to adjust to existing conditions and needs quickly. The right adjustment will make a lot of innovation output that can increase sales to customer satisfaction. The owner of SMEs must always update the knowledge of the current conditions of every situation of needs following the goods or services offered to create harmony with the conditions required by the customer. Second, the External Environment has a significant influence on Competitive Advantage in SMEs in Central Java. Changing environmental conditions can make SMEs continue to innovate, with one of them being implementing Competitive Advantage. By looking at the opportunities that exist, environmental conditions are very influential on the benefits derived from more value compared to other competitors. Third, Differentiation Strategy has a significant influence on Competitive Advantage in SMEs in Central Java. Succeeding research conducted by (Porter 1990). In contrast, one of the applications of Competitive Advantage is to carry out the Differentiation Strategy so that the creation of the Differentiation Strategy can arise in harmony with the application of the Competitive Advantage.

\section{Acknowledgments}

The authors want to express gratitude to our colleague for the useful supports through the learning process of this research. We want to thank our loved ones and friends, who have supported us throughout the entire process. We will be grateful forever for your love.

\section{REFERENCES}

[1] Adema, K. L., \& Roehl, W. S. (2010). Environmental Scanning the Future Event Design. International Journal of Hospitality Management, 29, 199-207.https://doi.org/10.10 16/j.ijhm.2009.10.017

[2] Daengs GS, A., \& Soemantri, A. I. (2020). Entrepreneurship Orientation Strategy, Market Orientation and its Effect on Business Performance in MSMEs. Ekspektra : Jurnal Bisnis Dan Manajemen, 4(1), 1-10. https://doi.org/http://dx.doi.or $\mathrm{g} / 10.25139 /$ ekt.v4i1.2163

[3] Darya, I. G. P. (2012). Pengaruh Ketidakpastian Lingkungan dan Karakteristik Kewirausahaan terhadap Kompetensi Usaha dan Kinerja Usaha Mikro Kecil di Kota Balikpapan. Jurnal Inovasi Dan Kewirausahaan, 1(1), 65-78.

[4] Ferdinand, A. (2014). Metode Penelitian Manajemen (Edisi 5). Badan Penerbit Universitas Diponegoro.

[5] Ghozali, I. (2012). Partial Least Square: Konsep, Teknik dan AplikasiSmartPLS 2.0 M3. Badan Penerbit Universitas Diponegoro.

[6] Gorondutse, A. H., \& Hilman, H. (2017). Influence of differentiation strategy on performance of hotels: the moderating role of environmental munificence. Journal of Business and Retail Management Research, 11(4), 150-161.

[7] Hartomo, G. (2019). UMKM Sumbang Rp8.400 Triliun ke Perekonomian Nasional pada 2018.

[8] Ingga, I. (2009). Pengaruh Lingkungan Eksternal, Lingkungan Internal, Strategi Kepemimpinan Biaya, Strategi Diferensiasi, Terhadap Nilai Pelanggan Dan Keunggulan Bersaing. Jurnal Aplikasi Manajemen, 7(2), 284-292.

[9] Job, M., Masayi, B., \& Nyongesa. (2016). Product Differentiation Strategy For Competitive Advantage In Kenya Cooperative Creameries. Africa International Journal of Management Education and Governance, 1(3), $1-9$.

[10] Katadata. (2020). Pemerintah Beri Stimulus, Berapa Jumlah UMKM di Indonesia?

[11] Kraja, P. Y. B., \& Osmani, E. (2015). Importance of External and Internal Environment In Creation of Competitive Advantage to SMEs. (Case of Smes, in the Northern Region of Albania). European Scientific Journal, 11(13), 120-130.

[12] Liao, S. H., Chang, W. J., \& Wu, C. C. (2010). An integrated model for learning organization with strategic view: Benchmarking in the knowledge-intensive industry. Expert System with Applications, 37, 3792-3798. https://doi.org/10 .1016/j.eswa.2009.11.041

[13] Malhotra, N. K., \& Dash, S. (2009). Marketing Research: An Applied Orientation (Fifth Edit). Dorling Kindersley Pvt. 
Ltd. Licences of Pearson Education in South Asia.

[14] Morden, T. (1993). Business Strategy and Planning. Mc-Graw-Hill Book Company. https://doi.org/10.1177/002 19436660030010

[15] Nurlina, R. N., Suparta, N., \& Sutjipta, N. (2013). Lingkungan Internal, Lingkungan Eksternal, dan Rahasia Jiwa Kewirausahaan sebagai Landasan Strategi Diferensiasi, serta Pengaruhnya terhadap Keunggulan Bersaing Usaha Mikro Tanaman Hias di Kota Denpasar. Jurnal Manajemen Agribisnis, 1(2), 1-15.

[16] Paryanti, R. (2015). Pengaruh Strategi Diferensiasi Terhadap Keunggulan Bersaing (Studi Pada Hotel Resty Menara Pekanbaru). JOM FISIP, 2(2), 1-12.

[17] Porter, M. E. (1990). The Competitive Advantage of Nations. The MacMillan Press Ltd.

[18] Putra, Y. S., Sudarmiatin, \& Suharto. (2018). Analysis of
Differentiation Strategies to Create Competitive Advantages in Facing Global Markets. The First International Research Conference on Economics and Business, 254-269. https://doi.org/10.18502/kss.v3i3.1888

[19] Sekaran, U. (2013). Research Methods for Business. Salemba Empat.

[20] Sugiyono. (2016). Metode Penelitian Kuantitatif, Kualitatif dan $R \& D$. PT Alfabeta.

[21] Türkay, O., Solmaz, S. A., \& Şengül, S. (2011). Strategic analysis of the external environment and the importance of the information: Research on perceptions of hotel managers. Procedia - Social and Behavioral Sciences, 24, 1060-1069. https://doi.org/10.1016/j.sbspro.2011.09.103

[22] Zimmerer, T. W. (2005). Essentials of Enterpreneurship and Small Business Management (Forth Edit). Pearson Prentice Hall. 